\title{
Why did distinct types of dual-earner models in Czech, Slovak and East German societies ${ }^{1}$ develop and persist?
}

\author{
Warum sind unterschiedliche Typen von Zweiverdienermodellen in der \\ tschechischen, slowakischen und ostdeutschen Gesellschaft entstanden \\ und warum bestehen sie weiter?
}

\begin{abstract}
:
We examine pre-1989 and post-1989 work-care models in Czech, Slovak and East German societies. Inspired by the institutionalist approach, we develop a framework that allows to analyze how, when and why two distinct work-care models evolved and persisted in the region. Once problems of the modernized gender model emerged, Czechoslovak and East German governments set the two countries on two distinct work-care policy paths. Consequently, fundamental differences in work-care practices and work-care related values and norms emerged between the two countries. Based on an examination of the institutional and cultural legacy, we explain why the transition from totalitarian to democratic regimes was accompanied by continuity in work-care models rather than radical departures from the previous models. In contrast to traditional institutionalist studies we point out that more recent institutional changes in the sphere of work-care policies in Czech, Slovak and East German societies did not occur as a consequence of the 1989 revolutionary
\end{abstract}

\begin{abstract}
Zusammenfassung:
Wir untersuchen Arrangements der Aufteilung von Erwerbsarbeit und Kinderbetreuung in Tschechien, der Slowakei und Ostdeutschland, vor und nach 1989. Basierend auf dem institutionalistischen Ansatz untersuchen wir, wie, wann und weshalb sich zwei unterschiedliche Arrangements in dieser Region entwickelt und durchgesetzt haben. Als die Konflikte des modernisierten Gender-Modells offenkundig wurden, schlugen die politischen Entscheidungsträger in der Tschechoslowakei und der DDR verschiedene Pfade ein, um Erwerbsarbeit und Kinderbetreuung in Einklang zu bringen. Infolgedessen entstanden zwischen den Ländern grundlegende Unterschiede in der Kombination von Erwerbsarbeit und Kinderbetreuung und in den damit verbundenen Werten und Normen. Wir erklären ausgehend von der Analyse des institutionellen und kulturellen Erbes dieser Länder, weshalb der Übergang von einem totalitären zu einem demokratischen Gesellschaftstypus mit einem hohen $\mathrm{Ma} ß$ an Kontinuität in den Arrangements der
\end{abstract}

1 The article was written with the support of European Commission grant project no. 028746-2 "FEMCIT: Gendered citizenship in multicultural Europe: The impact of the contemporary women's movement", grant project of the Grant Agency of the Academy of Sciences of the Czech Republic no. IAA700280901 "Institutions, myths and beliefs: An investigation of the influence of path dependency on the contemporary discourses on childcare in the Czech Republic, Sweden and France", and two grant projects of the Grant Agency of the Czech Republic, no. P404/10/0021 "Changes in partnership and family forms and arrangements from the life course perspective" and no. 403/09/1182 "The revenge of history? An examination of the historical roots of childcare, healthcare and elderly care policies in the Czech Republic". We thank Katrin Menke for help with the literature. We also thank the anonymous reviewer as well as the editors of the special issue for their helpful comments. 
period, but rather evolved in a period of relative stability.

Key words: dual-earner model, work-care arrangements, institutionalism, Central and Eastern Europe
Kombination von Erwerbsarbeit und Kinderbetreuung einherging. Ein zentrales Ergebnis unserer Untersuchung ist, dass neuere Änderungen der institutionellen Rahmenbedingungen der Vereinbarkeit von Beruf und Familie in Tschechien, der Slowakei und in Ostdeutschland nicht auf die massiven Umwälzungen im Zuge des Mauerfalles zurückgehen, sondern in einer Phase relativer Stabilität stattfanden.

Schlagwörter: Zweiverdienermodell, Erwerbsarbeits- und Kinderbetreuungs-Arrangements, Institutionalismus, Mittel- und Osteuropa

\section{Introduction}

The objective of our paper is to examine and explain pre-1989 and post-1989 continuities and changes in work-care models in the three neighboring Czech, Slovak and Eastern German societies. We were inspired by institutionalist theory to develop a framework that allows us to analyze how, when and why two distinct work-care policy paths and workcare models developed and then persisted until today in the region.

The goal of our article is thus threefold:

1) To show that two distinct work-care policy paths and work-care models developed in Czechoslovakia and the German Democratic Republic (GDR, for short, East Germany), which continue to influence the respective models today

2) To explain how and why the two distinct work-care policy paths and work-care models developed in these countries

3) To explain the continuity in the work-care models in Czech, Slovak and East German societies despite revolutionary changes in 1989, unification of East and West Germany in 1990, and the break-up of Czechoslovakia and the formation of the Czech and Slovak Republics in 1993.

Our framework stresses the role of work-care institutions, practices, norms and values, which influence each other and which are influenced by structural conditions and influential actors who contribute to reconceptualizing and reorganizing existing institutions through policy-making processes. Within this framework we can explain differences in work-care models between the respective countries as well as continuity and change in the work-care models within each country.

\section{The main differences between the two distinct dual-earner models}

Comparing Czech, Slovak and East German societies is particularly interesting because they shared many similarities in the past. Even though the three societies had many characteristics in common, two different versions of the dual-earner model evolved in the 
former Czechoslovakia and East Germany. Work-care models in Czech, Slovak and East German societies differed only slightly from those found elsewhere in continental Europe before the Second World War. Urban middle-class women took responsibility for the household and childcare tasks, while men were the only breadwinners. State socialist policies quickly departed from the gender-conservative male breadwinner model by encouraging all women to work outside the home. Income policies made it extremely difficult for families to live on one income and an increase in the number of public childcare institutions made it easier for mothers to work. Additionally, the absence of a male breadwinner in female-headed single-parent families after the Second World War (especially in Germany) and the ideology of women's emancipation through their lifelong fulltime employment played a role in diminishing the male breadwinner model.

Until the 1960s, Czechoslovakia and the GDR pursued similar work-care policies with similar outcomes. In both countries, a paid maternity leave of several weeks was offered to working mothers, and both governments established an extensive supply of childcare facilities. In terms of outcomes, both countries experienced relatively high employment among women and a rapid increase in accessibility and utilization of childcare institutions. However, in the late 1960s and during the 1970s, work-care policies diverged in Czechoslovakia and the GDR. East Germany's policies approached the Scandinavian model, which is considered the best promoter of gender equality to date. Similarly to the Scandinavian model but under the completely different conditions of a totalitarian regime, the East German government supported the continuous employment of mothers of small children. In contrast, state socialist Czechoslovakia - similarly to conservative Western countries - gave more support to mothers caring for their children at home. ${ }^{2}$ The establishment of these divergent work-care policies contributed to the gradual development of two distinct dual-earner models since significant differences in work-care practices, values and norms supporting them emerged.

Based on the study of the development of work-care policies, practices and discourses in East German, Czech and Slovak societies since the Second World War, we argue against the idea that there was just one state socialist work-care model in the countries of pre-1989 Central Europe. We agree with studies that categorize state socialist Central European countries as examples of the dual-earner model with state childcare (PfauEffinger 1998) or dual-earner/state-carer model (Crompton 1999). However, we go further in arguing that we have identified two distinct work-care models in East Germany and Czechoslovakia. Both models could be described as being extensive because both men and women worked mostly full-time and long hours. However, in Czechoslovakia an interrupted dual-earner model evolved, while in the GDR a continuous dual-earner model prevailed. The interrupted dual earner model can be characterized by continuity in men's careers and interruptions in women's careers. In contrast, the continuous dualearner model can be characterized by significantly less difference in the continuity in

2 While the government of the GDR introduced one year of income-related parental leave (called the Babyjahr) for mothers in 1976 in addition to extensive state support for childcare facilities, Czechoslovak leaders introduced two years of parental leave at a flat rate in 1970 (referred to as "extended maternity leave" in the following), which was gradually extended to three years (Klenner/Hašková 2010). 
women's and men's careers. Both dual-earner models were traditional in terms of men's gender role, because initially the right to parental leave was given to mothers only. ${ }^{3}$

Even today, after the countries went through radical post-1989 transformation, the main aspects that had distinguished East German and Czechoslovak work-care models persist in Czech, Slovak and East German societies. The Czech and Slovak Republics are among the European countries with the smallest percentage of children under the age of three in formal childcare. The former GDR, on the other hand, is a region with a high percentage of children under three in formal childcare (see OECD Family Database, available at www.oecd.org; Bothfeld et al. 2005). Moreover, the Czech and Slovak Republics rank among the European countries with the highest negative impact of motherhood on women's employment, while employment among mothers in East Germany remains high (European Commission 2008; Bothfeld et al. 2005). The establishment of the two distinct work-care policy paths and dual-earner models continues to affect the prevalence of attitudes toward gender roles to this very day. These gender role attitudes rank among the most traditional in Europe among Czechs and Slovaks, while attitudes of East Germans are among the most modern (Klenner/Hašková 2010). Although the transformation after 1989 brought some changes to the two distinct dual-earner models, these changes are modifications rather than radical departures from the two types. These modifications still reflect the cultural and institutional legacy under radically altered post-1989 conditions. In this paper, we explain why and how the two distinct work-care models developed and then persisted in the respective countries.

\section{Institutional analysis}

Our article ties into a very recent trend that investigates the connection between state socialist work-care policies and models and work-care policies and models in post-1989 Central and Eastern Europe (e.g., Heinen/Wator 2006; Bicksel 2006; Saxonberg/Sirovátka 2006; Saxonberg/Szelewa 2007; Hašková/Saxonberg 2010 forthcoming). This connection has been explained primarily within the historical institutionalist approach. Historical institutionalists focus on how institutions structure action and outcomes. They emphasize the importance of decisions that set countries on different policy paths. They argue that once countries follow a certain policy path, it becomes difficult to leave this path (Mahoney 2000). Policies are thus "path dependent." Historical institutionalists usually start at a point when several courses of action are possible. However, once a course of action (path) is chosen, it is easier to continue along the chosen policy path than to start a completely new course of action (Pierson 2000).

While historical institutionalists focus on the development of political institutions that follow the "logic of path-dependency," sociological institutionalists focus on social actors who act according to the "logic of appropriateness" in policy-making. While historical institutionalists stress the manner in which policy decisions set countries on different institutional paths (Mahoney 2000; Kenny 2007; Pierson 2000), sociological institutionalists

3 In the GDR, fathers obtained the right to a Babyjahr in 1986, while Czechoslovakia first offered parental leave to single fathers in 1985 . 
focus on the manner in which institutions influence cultural values, norms, ideologies and beliefs. When both approaches are combined, one could explore how cultural values, norms, ideologies and beliefs influence policies that tend to be path dependent and how, once established, institutions influence cultural values, norms, ideologies and beliefs (see Thelen 2004). The relationship between institutions and values shared by the population is not easy to study, however, because institutions and values are interdependent, each of them influencing the other (Voicu 2004: 232).

If applied to our particular case, a combination of historical and sociological institutionalist analysis could help us understand how ideologies, beliefs, values and norms influenced work-care policies in Czech, Slovak and East German societies and how the established work-care policy paths, in turn, influenced work-care ideologies, beliefs, values and norms in the three societies. Moreover, in our framework, both work-care policies and values and norms influence work-care practices. As Hobson and Fahlén (2009) put it, when explaining differences in work-care arrangements and gender models in Europe, it is laws and specific policies as well as norms and values that are legitimated and reproduced in policy and discourse that are crucial for gender equality in practice. According to them, path dependency is the core mechanism that explains patterns of institutional development, stratification outcomes in welfare states and the types of logic of gender regimes, that is, the extent to which welfare states weaken or sustain a male breadwinner model (see Lewis 1997). Similarly, Crompton states that "gender relations are produced and reproduced via already existing institutions, norms and practices, as well as through the ongoing relationship between individual women and men" (Crompton 1999: 19).

Moreover, we argue that not only institutions, values and norms influence practices. The relationship among all three - institutions, values and norms, and practices - is reciprocal. Work-care practices in given structural conditions can lead to conflicts; reflection on them can generate ideas, which can be seized by influential actors for reconceptualizing and reorganizing existing institutions. This takes us closer to the question of how institutional change happens if historical institutional paths and cultural norms "lock" actors into a certain path of institutional development.

Institutionalist studies have tended to focus on explaining the continuity of social policies rather than changes, and changes were usually explained as coming from outside as a result of exogenous shocks. However, recent institutionalist studies have increasingly sought to "endogenize" change. As Thelen (2004) puts it, even though existing institutional structures to some extent "lock" actors into a certain path, they do not completely determine future policy steps; there is room for innovation. This turn toward endogenous explanations of institutional changes has often meant a turn of attention to ideas and discourses. Those researchers who stress the role of ideas and discourse in explaining the institutional change work primarily within the tradition of historical, sociological, or, as Vivien Schmidt calls it, discoursive institutionalism. ${ }^{4}$ For historical institutionalists, institutions serve mainly as external constraints in terms of historical paths that shape action. For sociological institutionalists, institutions serve mainly as constraints in terms of cultural norms that frame action. Discoursive institutionalists take a more dynamic ap-

4 Less often within the tradition of rational choice institutionalism (Schmidt 2010), which we do not refer to, and thus leave the discussion on this type of institutionalism out of scope of this paper. 
proach to institutions. For discoursive institutionalists, institutions serve as structures that constrain action as well as constructs created and changed by agents. However, as Schmidt recently emphasized, empirical evidence of how, when, where and why ideas and discourse matter for institutional change still remains underexplored (Schmidt 2010).

Similarly to Schmidt, Pfau-Effinger emphasizes the interplay between cultural ideas, path-dependent institutions and social actors and argues that a care arrangement can be firmly established and coherent in the long term if its cultural foundations are embedded as norms at the level of institutions and actors' behavior (Pfau-Effinger 2005). Transformation of care arrangements can be expected primarily if certain agents seize contradictions in those arrangements. Then the arrangement can become the object of conflict and negotiation concerning innovative models or new institutional arrangements. These conflicts can take the form of discoursive struggles for interpretations that precede policy change. Success of new discourses usually depends on the extent to which they pick up on trends or contradictions in the attitudes of the general public in favor of the changed values (Schmidt 2010).

Similarly to Pfau-Effinger (2005) and Schmidt (2010), in our framework, we do not define institutions only as constraints but also as constructs and stress the importance of influential actors and discourses to maintain, modify or change established institutions. Moreover, we point out that differences in the mechanisms of institutional change in democratic and totalitarian regimes can be expected because totalitarian societies suppress freedom of speech and limit the number, diversity and opportunities for social actors to act publicly. Thus, a single actor or decision could be much more influential under a totalitarian regime due to limited opportunities for critical evaluation, public debate and democratic negotiation of political measures.

Work-care model: Interplay of institutions, pracitces, and norms and values

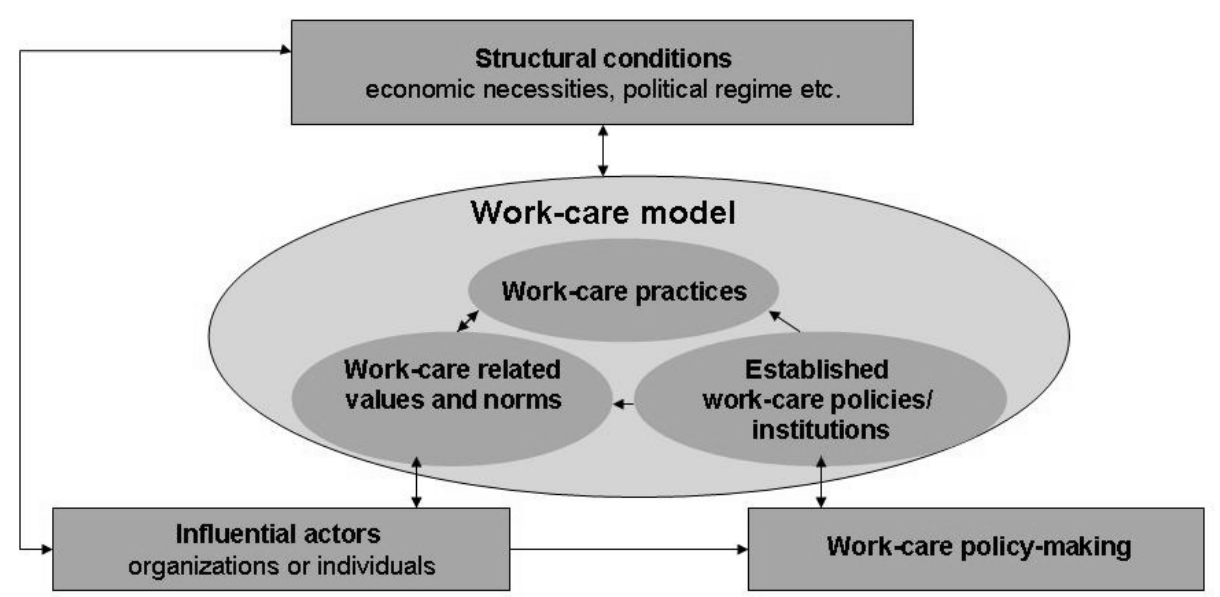

Inspired by the theoretical discussions within the above mentioned institutionalist traditions, we developed a framework that helps us examine how, when and why two distinct work- 
care policy paths and work-care models emerged and continue to persist in Czech, Slovak and East German societies despite the revolutionary changes that came about in the region. The framework emphasizes the interplay between work-care institutions (as constructs and outcomes of work-care policies and as structures that influence the development of further work-care policies), work-care related norms and values expressed in beliefs, ideologies and dominant discourses, and work-care practices. These three elements - work-care practices, norms and values, and institutions - constitute a work-care model, which is further affected by structural conditions (such as economic necessities) and influential actors who may strengthen specific discourses and bring about institutional change.

\section{Toward a dual-earner model - The Marxist ideology of women's emancipation and institutional arrangements to achieve it}

Processes of women's individualization, including the growth in women's employment and the decline of the male breadwinner model, characterize the era after the Second World War in all European countries. However, women's employment grew faster and to a larger extent in the state socialist countries than elsewhere in Europe. The post-war need for paid work was accompanied by the introduction of the centrally planned economy in the former Eastern Bloc. The centrally planned economy was supposed to reduce poverty and class differences. Massive investments were made to stimulate industrial growth and the notion of women's emancipation through their economic independence from men was promoted.

After 1948, when the communists came to power in Central and Eastern European countries, all existing institutions and policies had to be quickly (re)constructed to follow the Soviet model. The male dominated character of the state and the Communist Party as well as the lack of democracy led to a "patriarchal way" of women's liberation "from above" (Nickel 1993). Although some influential women were involved in the process, there was no chance for masses of women to articulate their needs. Since childcare was crucial for increasing the number of women in industry, similar childcare policies were introduced in all state socialist countries. The introduction of paid maternity leave of several weeks was accompanied by education and healthcare reforms that firmly established kindergartens (childcare institutions for preschool children from the age of three) as educational institutions under control of the ministries of education. Crèches (childcare institutions for preschool children below three years of age) were considered healthcare institutions and were monitored by the ministries of health. Instead of educators, the main responsibility for childcare in crèches was thus given to children's nurses.

Affected by the newly introduced policies and the economic needs of the family, the share of women in the labor force and the share of children in public childcare increased drastically in Czechoslovakia and the GDR. Due to long working hours and the ongoing expansion of round-the-clock enterprises, the number of children increased not only in daycare facilities but also in childcare facilities covering all workdays of the week. In those facilities, children stayed during the week and parents took them home only for the weekend. An official ideal was established and promoted in the media stressing that "only a working mother who strengthens the workers' and peasants' state ... is a good mother" 
("Frau von heute" 1955 cited in Paterak 1999: 237), whereas housewives were denigrated.

However, this extensive dual-earner model brought about many problems. Despite the official ideal and governments' promises to help working mothers, a lack of childcare and household services together with long working hours and the shortage economy contributed to women's double burden. Subsequently, the double burden on working mothers started to be criticized in the media (Schröter 2009) and to be documented by researchers who analyzed time use surveys and public opinion polls (Háková 1966) in the 1960s. In both countries many mothers preferred to work part-time as a result of the difficulties related to combining work and family (von Oertzen/Rietzschel 1997; Srb/Kučera 1959). However, party leaders saw women's affinity to part-time work as a "lack of ideological clarity" (Schröter 2009: 43). Childcare facilities were overcrowded, which was one of the reasons for a higher illness rate among children in crèches. ${ }^{5}$ Moreover, research uncovered detrimental development among children who were raised in long-term institutional childcare, mainly in permanent institutional care (e.g. in children's homes), but also in week-long institutional care, particularly crèches (see e.g. Koch 1963:12). Although the Soviet model officially supported long-term institutional childcare in the $1950 \mathrm{~s}$, research findings led policy makers to come to the conclusion that these forms should be given up, which was then followed by a rapid decline in the share of week-long crèches in the first half of the 1960s (Buliŕr 1990; Niebsch et al. 2007).

\section{Setting up two different work-care policy paths and two versions of the dual-earner model}

The popular paradigm presents the state socialist regime in the Eastern Bloc as homogenous in devaluing the full-time female carer and in celebrating working mothers. However, research shows that there were fundamental differences in the discourse, policies and work-care practices between state socialist countries of the Eastern Bloc. In the 1960s, Eastern Bloc governments had to deal with three major problems linked to the promotion of the state socialist women's emancipation project: declining birth rates, working mothers' double burden and the aforementioned high illness rate among children in crèches. Although these problems were discussed widely in the public media in the Eastern Bloc in the 1960s, open civil society discussion about proper ways to solve these problems could not take place in the totalitarian regime. The country leaders decided to establish state bodies that would focus on the issue of motherhood and women's employment. These bodies became important actors whose policy proposals and the discourse they promoted contributed to the establishment of the two different work-care policy paths and dual-earner models in Czechoslovakia and the GDR.

5 E.g. in 1964, there were only 58,000 places in crèches for 280,000 children of employed mothers in Czechoslovakia. The Czechoslovak National Assembly discussed this ratio as one of the reasons for the high illness rate among children in crèches (transcript of speeches of the Czechoslovak National Assembly on the 1st of April 1964, accessible at http://www.psp.cz/eknih/1960ns/stenprot/025 schuz/s025001.htm). 
In the GDR, the Socialist Unity Party in power dealt with women's issues in a special party committee. In addition, a scientific advisory committee was established in 1964 called The Woman in Socialist Society ("Die Frau in der sozialistischen Gesellschaft"). This scientific committee emphasized the role of time budgets in the reconciliation of work and family and proposed measures to ease the burden on working mothers. The government later introduced some of these measures, such as a proposal to reduce women's working hours.

Although the right to part-time work for mothers was introduced in the Labor Code ("Arbeitsgesetzbuch") as early as 1961, the party frowned upon part-time work. Only $16 \%$ of women worked part-time in 1960 . However, the need to alleviate the time burden on working mothers was urgent and women were increasingly able to have their request for a part-time job approved. The percentage of women working part-time grew to $33 \%$ in 1975 and has never dropped below $27 \%$ since but it shall be mentioned that a considerable part of this share were women of pre-retirement age.

Moreover, in 1972 working time was reduced to 40 hours per week among mothers who worked shifts and had two or more children and among mothers who worked fulltime and had three or more children while they retained their full salary. In addition, mothers with two or more children received an additional three to nine days of holiday. Shortly thereafter, in 1977 the working time was reduced to 40 hours for all mothers who worked full-time and had at least two children.

The emphasis on the time issue of mothers' employment was also a consequence of the fact that the debate in the GDR never questioned the goal of achieving uninterrupted full-time employment of all women including mothers of very young children. Therefore, the question regarding childcare for babies and toddlers was never whether collective care was beneficial for children but how it could be improved. ${ }^{7}$ The physician and scientist Eva Schmidt-Kolmer, who held leading positions in the GDR's health-care administration, played a decisive role in research on childcare and child development, and consequently promoted the public acceptance of crèches (Niebsch et al. 2007). In 1966, the Institute for Social Hygiene ("Institut für Sozialhygiene") was founded, which reflected the existing critical discourse on the detrimental effects of long-term (and long hours) institutional childcare. Under Schmidt-Kolmer's leadership the institute studied how to provide quality childcare in childcare institutions, mainly in day crèches. The first issue addressed was the high illness rate among children in crèches (Reyer 1996). Based on the recommendation by the Institute for Social Hygiene, opening hours in crèches were shortened from 14 to 12 hours a day. At the same time, mothers were allowed to adjust their work schedules to the opening hours of the childcare facilities even though the opening hours remained long.

The percentage of children in childcare facilities grew rapidly as a result of the expansion and improvements in childcare facilities. In the 1980s, the share of children under the

6 "The Woman in Socialist Society" cooperated with trade unions (which were seen as "transmission belt" of the political party), the editorial board of the leading women's journal For You ("Für Dich") and other actors. The few attempts of the women's mass organization Democratic Women's Association of Germany ("Demokratischer Frauenbund Deutschlands" (DFD)) to express women's interests independently were suppressed (Schröter 2009).

7 Information based on an interview with Herta Kuhrig (January 27th, 2010). 
age of three in crèches in the GDR reached $80 \%$ and the share of preschool children from the age of three who attended kindergartens reached $90 \%$ (Statistisches Jahrbuch der DDR 1989; Winkler 1990). In line with the increase in childcare facilities, the employment rate of women in the GDR increased from $52 \%$ in 1950 to $89 \%$ in the late $1980 \mathrm{~s}$ (Klammer et al. 2000). ${ }^{8}$ The ideal of a working mother in all adult stages of her life cycle became widely accepted and practiced. The dual-earner model became firmly embedded in work-care policies, practices, values and norms in the GDR.

However, other ideas and policy proposals were discussed before the policy path based on strong support of childcare facilities became established, and mothers' working hours were reduced in the GDR, too. In the 1960s, the introduction of a three-year maternity leave was suggested as a compromise between mothers' continuous full-time employment and full-time care. This proposal was rejected with reference to compromising women's emancipation. Part of the story was, however, that on the structural level, labor demand in the GDR was still high.

In Czechoslovakia, different advisory bodies were established in the 1960s that were intended to deal with the consequences of growing female employment. In 1965, on behalf of the Communist Party, the Czechoslovak Union of Women was founded. The union had the right to comment on laws relating to the position of women and families in society and to submit their own proposals. This was done through the Government Population Commission, which was an advisory body to the Czechoslovak government established in 1959 (Uhde et al. 2009). ${ }^{9}$ Similarly to other countries of the former Eastern Bloc in the 1960s, the Czechoslovak government supported the idea that family and women's issues should be addressed by scientists. But while in the GDR, the scientific committee The Woman in Socialist Society emphasized the time issue of working mothers and how to organize quality care in childcare institutions, the main goal of the Czechoslovak Government Population Commission was to combat the fertility decline. ${ }^{10}$

In 1968, in line with the discourse on the need to alleviate the time burden of working mothers, the Czechoslovak Union of Women demanded the supply of part-time jobs. ${ }^{11}$ The Union also demanded working hours for mothers being reduced to six hours per day at full wage compensation. In line with the discourse on the detrimental effects of long-term (or long hours) institutional childcare, the Union also demanded opening hours of crèches to be reduced to six hours a day. All these demands were similar to the proposals by the East German scientific committee The Woman in Socialist Society and the Institute for Social Hygiene. None of these demands by the Union were implemented, however. The Union was successful in demanding another policy: the introduction of paid extended maternity leave.

8 Table 2A3b on CD-ROM: The provided data are based on various sources, and thus cannot be compared with similar indicators directly.

9 The Government Population Commission was chaired by the federal vice prime minister. Its members included researchers, vice-ministers of several ministries and representatives of trade unions, the Czechoslovak Union of Women and some other organizations (United Nations 1979).

10 The party leaders in the GDR were concerned by falling birth rates, too. However, political measures to increase fertility were introduced only in the late 1970s when public acceptance of crèches was already high.

11 Part-time jobs were supposed to be available for mothers with dependent children since the adoption of the 1956 Czechoslovak Labor Code but companies mostly denied to offer part-time jobs with reference to operational difficulties (Srb/Kučera 1959). 
However, this particular demand was also the most controversial within the Czechoslovak Union of Women. Some of its members called for a paid maternity leave of three years. Studies by psychologists and pediatricians on the detrimental effects of overcrowded crèches with long opening hours contributed to the formulation of this demand. As in the GDR, members of the Union also argued that such a long duration of maternity leave would hamper women's emancipation. Following negotiations among the Union's members, the Union demanded two years of paid extended maternity leave together with the reduction of mothers' working hours and an improved as well as increased supply of crèches. ${ }^{12}$

Two main institutional and structural factors contributed to the success or failure of the Union's policy proposals. On the institutional level, the Czechoslovak Union of Women was supposed to submit their policy proposals on work-care issues in coordination with the male-dominated Government Population Commission. The commission focused on how to stop the fertility decline. Since it seemed to be connected to the increase in women's employment, the commission supported an extended maternity leave as a pro-natalist measure. Of course, it was expected that the number of employed women would decrease if this pronatalist measure was applied. The economists argued though, that the decrease would not cause any economic problems because there was no longer any deficit in labor supply in the female-dominated areas of industry in Czechoslovakia. When two years of paid extended maternity leave were introduced in 1970-1971, the Czechoslovak National Assembly argued that even though the allowance would be expensive, there would be less demand to build costly crèches and fewer expenses for employed mothers on sick leave to care for their ill children. Thus, to stop the fertility decline, it was argued that priority should be given to women's reproductive role during the first years after childbirth. ${ }^{13}$

Although the intention to extend the paid maternity leave up to three years was officially declared in the 1960s (Klíma 1969), this plan was implemented only gradually during the 1970s and 1980s. Since mothers had the option of staying at home on an extended maternity leave, the number of crèches in Czechoslovakia increased much more slowly than in the GDR since the 1970s. Moreover, as less financial support was given to crèches and no such institute as the East German Institute for Social Hygiene existed in Czechoslovakia, the quality of crèches did not improve as quickly as in the GDR.

While in the GDR the official media discourse promoted the acceptance of public childcare, in Czechoslovakia no such trust emerged. Instead the public discourse depicted crèches primarily as facilities to support single mothers (due to economic reasons) and highly career-oriented women (Klíma 1969). ${ }^{14}$ Consequently, the belief that women's employment was harmful to young children became much more common in Czechoslo-

12 An extended maternity leave had already been introduced in Czechoslovakia in 1964. However, this leave was available only until the child reached the age of one year and it did not include any financial benefits. Consequently, many mothers did not take advantage of it due to financial constraints.

13 See transcripts of speeches at the Czechoslovak National Assembly (http:/www.psp.cz/cgi-bin/ascii/ eknih/1969fs/sn/stenprot/006schuz/s006007.htm; http://www.psp.cz/eknih/1960ns/stenprot/025schuz/ s025001.htm).

14 While psychological and pediatric advisory literature of the 1960s described crèches as a positive supplement to family childcare, the 1970 s witnessed a debate, which increasingly perceived crèches as support facilities, compensating the limited time budgets of career-oriented mothers and lowincome families (see e.g. Mečír 1962; Koch 1963; Schiller et al. 1971; Langmeier/Matějček 1974; Švejcar 1985). 
vakia than in the GDR. While career interruptions became considerably shorter during the state socialist regime in the GDR (Trappe 1995: 135), mothers in Czechoslovakia stayed on leave increasingly longer, and interruptions in women's careers were not just institutionalized but also socially accepted (Klenner/Hašková 2010). As a consequence, different norms emerged in the two countries. In contrast to the increasing normality of crèche care for children under three years in the GDR, which strengthened the norm of the mother working at all stages of her life, the ideal of full-time maternal childcare for children up to age three became internalized as a social norm in Czechoslovakia (Čákiová et al. 1977; Kreipl et al. 1979).

As a result of the policy path of extending the paid maternity leave in Czechoslovakia, the percentage of employed women in general was rather high (Pascall and Kwak 2005) and the share of preschool children in kindergartens reached relatively high levels, but the share of children under three in crèches stayed much lower than in the GDR. While $94 \%$ of three to five-year-old children were in kindergartens in the Czech part of Czechoslovakia and $86 \%$ in Slovakia, only $18 \%$ of children younger than three were in crèches in both the Czech and the Slovakian region in the mid-1980s (Historical Statistical Yearbook of Czechoslovakia 1985).

To conclude, using our framework, we explained how the two distinct work-care policy paths and extensive dual-earner models developed in the GDR and Czechoslovakia despite previous overwhelming similarities in this area. In the 1960s, the main conflicts arose in both countries on account of women's mass entry into the labor force. These conflicts were reflected in public discourse in Czechoslovakia and the GDR with limited possibilities of various actors to act publicly. While Czechoslovak policy focused on extending maternity leave in order to combat the fertility decline, the policy of the GDR concentrated on expanding and improving the public infrastructure of childcare facilities. The GDR invested in improving the quality of crèches, cut working hours for mothers slightly and allowed mothers to work part-time. In contrast, Czechoslovakia introduced extended maternity leave so that women could concentrate on home-based care until their children reached the age of three years. The different policies affected work-care practices which started to diverge significantly in the two countries at the beginning of the 1970s. Moreover, the many years of distinct work-care practices under the impact of specific work-care policies in the two countries translated into radically different work-care related values, norms and beliefs in the two societies.

\section{The legacy of the policy paths chosen and continuity of work-care models}

Despite the revolutionary changes that Czech, Slovak and East German societies underwent after 1989, the societies experienced overall continuity of the two distinct work-care models and work-care policies.

First of all, the unification of East and West Germany meant applying the familialist policies of West Germany that supported the male breadwinner model to East Germany in the 1990s. This gave East German mothers incentives to take longer career breaks. Splitting of the couple's income for tax purposes, free health co-insurance for non-working wives and three years of parental leave with a two-year means-tested childcare allowance 
became available. ${ }^{15}$ Nonetheless, a deeply rooted continuous dual-earner model with a broad supply of public childcare continued to influence work-care practices in East Germany even after unification. The work-care policies applied earlier created institutions people were accustomed to and affected their beliefs, values and norms. Unlike policies at the federal level, state and community officials in the federal states in eastern Germany were aware of the established East German dual-earner model and did not dare to reduce support for public childcare facilities excessively. The continuous dual-earner model was deeply rooted in the East. Families also depended on the woman's income and spouses depended economically on each other. Moreover, the percentage of households with a female main (or sole) breadwinner increased (Klenner 2009). In several East German states, the right to childcare was even codified so that the familialist tendencies could not thwart the network of existing childcare facilities. The high ratio of all-day kindergarten places in East Germany remained widely stable from the late 1980s on. Although the percentage of children in crèches has decreased because some mothers take advantage of the longer parental leave, two-fifths of children under three still receive formal childcare and every second mother of a child between two and three years of age is gainfully employed in eastern Germany (Bothfeld/Tobsch/Schmidt 2005: 12).

While East Germans experienced the introduction of familialist policies during the 1990s as part of the implementation of "foreign" West German policies in their society, Czechs and Slovaks experienced familialist policies during the 1990s as a continuation of the policy path previously chosen. Since childbirths had already begun to drop in the 1980s and since Czechoslovakia introduced three years of paid maternity leave to reduce the demand for costly crèches, Czechoslovakia had already begun to reduce the number of childcare facilities in the 1980s. This trend persisted in the Czech Republic and Slovakia over the 1990s. While the ministries of education in the two countries continued to provide subsidies to kindergartens after 1989 and the decline in the number of kindergartens corresponded with the decline in fertility, crèches as healthcare facilities were excluded from the list of facilities supported by the ministries of education after 1989. Consequently, crèches disappeared entirely in Slovakia. In the Czech Republic crèches provide care to less than $1 \%$ of children under three. ${ }^{16}$ Given the institutional path dependency that established the interruption of female work careers due to childcare as a norm, it is no surprise that there was no public protest against canceling subsidies to crèches. Czechs and Slovaks were convinced that it was better for children under the age of three to stay in their mother's care. Moreover, the legacy of relating childcare institutions for young children to the domain of healthcare persists so that even today, private child-minders are required to have a medical certificate to be allowed to care for children under the age of three.

However, it is unlikely that path dependency completely determines future development. Within established institutions, actors have some room to maneuver. Thus, some differences emerged between the Czech Republic and Slovakia after the two countries

15 West Germany introduced parental leave in 1986. It was extended to three years in 1992. There was a flat rate payment for up to two years until 2007.

16 A similar situation occurred in the other countries of the Visegrád Group (which consists of the Czech and Slovak Republic, Hungary and Poland) that established the dual-earner model with women's interrupted career (Szikra 2010). 
separated. Since the new leaders in the Czech Republic feared growing unemployment, they decided to encourage mothers to stay at home by further extending the childcare allowance for full-time mothers of children even up to the age of four in the mid-1990s. In Slovakia, the previous policy remained unchanged, providing a paid leave for children up to age three. As a result of the extension of childcare allowance in the Czech Republic and in light of the decline in childcare facilities and growing unemployment, Czech mothers prolonged their absence from the labor market due to childcare during the 1990s. More than $25 \%$ of mothers stayed home for more than three years, while the majority stayed home for three years. Recently, only half of Czech mothers returned to their previous workplace. In a European comparison, the negative impact of motherhood on women's employment was most pronounced in the Czech Republic followed by Slovakia and Hungary (European Commission 2008). Since the childcare allowance was extended to up to four years, while the reinstatement rights remained limited to three years, mothers partly misunderstood the discrepancy between the two time limits and lost their jobs after their child's third birthday. Others who had to give up their job after the three year leave period because they were unable to obtain a place in a daycare facility, did not receive unemployment support as the status of "being in unemployment" remained effective until their eligibility for maternity leave ended with the child's fourth birthday.

Based on the institutional legacy, one can witness how the work-care policy path previously chosen and the related dual earner model with interruptions in women's careers negatively influenced mothers' employment when centrally planned economies transformed into market economies. While mothers were used to interrupt their employment for rather long periods under the impact of an extended maternity leave, they did not have to fear unemployment under conditions of a centrally planned economy. In the market economy the interrupted dual-earner model weakened the labor market position of mothers in particular.

Yet another factor contributes to the negative impact of motherhood on women's employment that has arisen from the state socialist legacy. Both the Czech Republic and Slovakia have a culture of long working hours and full-time employment. This is typical of countries of the former Eastern Bloc. The percentage of women working part-time in the Czech Republic is about $10 \%$ while the percentage of men working part-time is about $3 \%$ (Czech Statistical Office 2010). In Slovakia the overall percentage of those working part-time did not exceed 5\% for women or $2 \%$ for men in the last decade (Gerbery 2010). In fact, mothers in the two countries can choose from only two options, which were the same two choices available during the state socialist regime: either to stay at home fulltime or to return to work full-time. This results in the fact that in the Czech Republic and in Slovakia women who continue to work after childbirth often do not reduce their working hours, while women who do take a temporary leave tend to change their employer quite frequently. Interestingly, this pattern, which is quite common in the Visegrád countries (also including Hungary and Poland) deviates from most other European countries, where woman return to the same employer but tend to reduce their working hours after childbirth (Riedmann et al. 2006). Although the GDR established a dual-earner model, which was also extensive in terms of working hours, East German institutional arrangements enabled more mothers to work part-time even during the state socialist regime. East German mothers returned to work earlier than Czechoslovak mothers and they returned to 
work part-time more often than Czechoslovak mothers during the state socialist regime. After 1989, the Czech Republic and Slovakia sustained their previous policy of long-term maternal leave and their institutional arrangements on the company level continued the legacy of full-time employment. In contrast, East German women gained more opportunities for part-time work since a federal law promotes part-time work, though some women work part-time involuntarily. ${ }^{17}$ Czech and Slovak mothers substantially increased the time spent at home taking care of their children full-time after 1989.

Moreover, the work-care policy path previously chosen and the related work-care model can even help us understand the following contradiction. While the former Eastern European countries departed from the male breadwinner model earlier than the rest of Europe, attitudes toward combining paid work and motherhood remained rather conservative in a significant number of these countries. The institutional legacy helps us explain why, in a European comparison, these countries, such as the Czech Republic, Slovakia and Hungary, show the highest levels of agreement with both of the following types of statements: "Both women and men should contribute to household income" and "A preschool child is likely to suffer if his or her mother works". ${ }^{18}$ In contrast, of all Europeans, East Germans have the most positive opinions of combining mothers' gainful employment and care for preschool children (Klenner/Hašková 2010). These results correspond to East Germany's institutional legacy, which led to a dual-earner model with continuous female employment trajectories and an extensive use of childcare facilities for children of all ages. On the other hand, the Visegrád countries' institutional legacy, established a dual earner model with interrupted work careers of women who take responsibility for fulltime care at least for the first three years of their children's lives.

Similar results could be observed when testing agreement with a statement reflecting the traditional division of gender roles: "A man's job is to earn money; a woman's job is to look after the family" ${ }^{19}$ The most traditional attitudes toward gender roles are found in those former state socialist countries where the dual earner model with interrupted women's careers had developed as the dominant work-care practice as well as the norm. The exception that East Germans represent in the former Eastern Bloc with regard to their attitudes toward gender roles (they are the most modern in Europe) can be explained by their distinct institutional legacy. The East German dual-earner model with uninterrupted female employment trajectories has diminished the differences in women's and men's life courses. Consequently, it also weakened the belief in separate gender roles. In contrast, the dual-earner model with interrupted female careers has strengthened the discourse on the conflict between mothers' work and small children's interests.

To conclude, the example of crèches in the Czech Republic and Slovakia shows how institutions can influence values, norms and beliefs and hinder other institutions from being established based on the logic of appropriateness and institutional path. If crèches had

17 With $48 \%$ of all East German mothers with a child aged 14 or younger working part-time (Statistisches Bundesamt 2008), it is up for debate whether East Germany has begun to move from a dual-earner model towards a one-and-a-half-earner model. Data, however, suggest that there is a tendency toward more differentiation among couples. It seems that earner models have diversified meanwhile (Klenner 2009).

18 Source: ISSP surveys 1994 \& 2002: http://www.issp.org/.

19 Source: ISSP surveys 1994 \& 2002: http://www.issp.org/. 
not been legally defined as healthcare institutions in the 1950s and if they had not been the only facilities providing day care for children under the age of three, the belief that non-family care for young children has to be provided by healthcare professionals would not have emerged. In the latter case, private alternatives to crèches would have been able to be established more easily in Czechoslovakia and, subsequently, in the Czech Republic and Slovakia after 1989.

In the case of East Germany, we showed how, based on the logic of appropriateness, once established, work-care policy hindered policy change on the state and community level when familialist policies were applied on the federal level. Once established, East German work-care policy affected East Germans' work-care related values, norms and practices, and thus the leaders did not dare to reduce support to childcare facilities on the state level. On the state and company level, East Germany continued to follow the policy path previously chosen and resisted the "foreign" familialist tendency. In contrast, the Czech Republic and Slovakia also continued to follow the policy path previously chosen that had already included the familialist tendency. On the level of work-care models, East Germans continued the practice of mothers taking relatively short career breaks, relatively high usage of crèches and an increasing number of mothers working part-time under the new conditions after 1989. Czechs and Slovaks, on the other hand, continued the practice of mothers taking increasingly long career breaks and low usage of crèches, which became almost non-existent under the new conditions after 1989.

Last but not least, we even showed how an institutional approach can help answer the question of how it is possible that the Czech Republic and Slovakia, which were among the forerunners in abandoning the male breadwinner/female carer model in Europe, currently display one of the most traditional attitudes toward gender roles. The work-care policy, which firmly established the sequence of women's life course in Czechoslovakia, revived the discourse on differences between women's and men's roles. In contrast, in the GDR, the policy and practice of the dual-earner model with continuous women's careers weakened the belief in separate spheres.

\section{Post-1989 opportunities for institutional change}

In line with the traditional institutionalist approach, we focused on the continuity in work-care policies in the previous section of this article. However, we showed that exogenous shocks do not necessarily cause substantial institutional changes. Despite the 1989 revolution, dissolution of Czechoslovakia and unification of Germany, work-care policies on the state and company level continued to follow the policy paths previously established in Czech, Slovak and East German societies. In contrast to the classical institutionalist studies, in this section of this article, we will show that substantial institutional changes in the realm of work-care policies occurred in the three societies after 1989 in a time of relative stability, independent of the exogenous shocks experienced around 1989.

The extensive interrupted dual-earner model contributed to a steady rise in long-term unemployment and economic inactivity among mothers in the Czech Republic and Slovakia after 1989. During the EU accession process, the two countries were criticized 
for their neglect of an active and effective employment policy. To fulfill the EU accession requirements but also because of internal factors like growing pressure from women's organizations and the economic need to promote continuous employment of highly qualified mothers, the Czech and Slovak governments introduced active employment policy measures. Moreover, the 2002 Barcelona agreement, which requires all European countries to ensure access to care services for one-third of children under three and $90 \%$ of preschool children from the age of three, started to be discussed in these countries. After 1989, newly established feminist groups started to use the EU discourse strategically to lobby for their goal of protecting mothers from long-term unemployment. However, their demand that state financial support for crèches be reinstated was strongly denied by the Czech and Slovak governments and conservative women's groups, which emerged after 1989.

While feminists were not successful in their claims for state funding of crèches, Czech feminists succeeded in implementing several modifications to the childcare allowance when Social Democratic governments were in power (1998-2006). Czech feminists established very close ties to these governments. Consequently, the childcare allowance for a full-time carer (usually the mother) was modified gradually so that a parent receiving the childcare allowance is permitted to have an unlimited income from gainful work activity and to use childcare facilities for a limited number of days or hours a month. These modifications were made to enable mothers to attend requalification courses, find a new job, maintain contacts with their previous employer, work from home or on short-term projects while childcare facilities take care of their children. Moreover, two other modifications to the childcare allowance were made during the subsequent right-wing government. In 2007, the real value of the allowance, which had decreased, was increased to $40 \%$ of the average wage in the public sector, making it easier for some parents to afford private childcare. In 2008, a three-tier system of parental leave was established based on the idea that the shorter the leave (two, three or four years), the higher the pay per month. However, even if mothers want to return to work earlier, they have few possibilities of doing so since virtually no places in crèches are available. Since private child-minders of children under three are too expensive for most, this measure seems aimed at the more affluent. Despite these shortcomings, the modifications to the childcare allowance show how small gradual corrections of an established institution may result in a complete redefinition of the institution. In other words, small changes that seemed to be just small corrections within the chosen policy path brought about a completely different philosophy of the childcare allowance. While the allowance was introduced in Czechoslovakia in the 1970s as a financial contribution to full-time mothers to enable women to segment their life into reproductive and paid work periods, today the allowance functions as a financial contribution to care for small children provided on a private basis without regard to parents' current economic (in)activity.

Similarly to the Czech gradual redefinition of the childcare allowance, the Slovak government introduced a completely new childcare allowance in 2008. Only parents who work or attend a secondary school or university and provide childcare with the help of other persons, private entities or child-care facilities can apply for the new allowance. This means that in Slovakia parents can currently choose between being on paid parental leave full-time until the child reaches the age of three or working in the labor market and 
receiving the new allowance, which covers part of the non-family paid childcare. According to Gerbery (2010), similarly to the Czech Republic, the problem of long-term unemployment of mothers played a major role in introducing the new childcare allowance. The introduction of the new childcare allowance in Slovakia and the modification of the allowance that had been previously established in the Czech Republic show that both governments decline to invest in public childcare for young children and both governments rely on the increasing supply of private child-minders. In contrast to public childcare, the idea of private child-minders is in accordance with the ingrained belief that children under three should be cared for at home.

Yet even Germany changed its federal childcare policy in 2007 to keep mothers in the labor market because of the fear that the workforce will decline due to demographic changes. The previous three-year parental leave accompanied by the means-tested flatrate allowance was replaced with a Swedish-type income-related $12+2$ month parental leave, which includes two additional months if "the other parent" (usually the father) stays at home for at least two months. Moreover, the federal government promised to increase support for daycare to fulfill the 2002 Barcelona agreement. The shift in the EU bodies that began to push forward women's employment because of the declining workforce due to demographic changes contributed to these radical changes in childcare policy in Germany, which had already been the goal of both western and eastern German feminists as well as of several influential female politicians for many years. Both changes were accompanied by massive attacks from conservative politicians, however. This shift in policy moved Germany closer to the East German dual-earner model and further from the West German specialization model. The West German specialization model proved to lead to low employment rates among mothers and a high percentage of childlessness. The Swedish-type parental leave in Germany resembles the East German income-related Babyjahr. However, it includes incentives for fathers to participate in childcare, an aspect that was missing in the East German state socialist work-family policy. Addressing fathers and promoting the shared responsibility of both parents for childcare was a longstanding objective of the women's movement.

All three national cases need more space to discuss arguments on the interplay between established work-care institutions, norms and values, and practices, which, together with changing structural conditions (e.g., population aging) and influential actors, brought about the described institutional changes, which seem to privilege the more affluent families. The economic need for highly qualified women combined with the fear of economic sustainability being undermined in an aging Europe may strengthen class differences in work-care practices in all three societies. Although an explanation of how and why the changes mentioned above happened is beyond the scope of this article, all three cases show that post-1989 important institutional work-care changes did not occur as a result of exogenous shocks. On the contrary, they happened during a time of relative stability and were brought about by influential actors that seized selected problems and discourses. 


\section{Conclusion}

In the popular paradigm, the state socialist period is often depicted as homogenous in devaluing full-time mothers and celebrating working mothers. Despite the fact that Czechoslovakia and East Germany shared many similarities and had the same work-care policies in the first phase of the state socialist regime, our analysis showed that - once contradictions of the modernized gender model emerged and started to be discussed in the 1960s the Czechoslovak and East German governments employed different policies to deal with these contradictions. Consequently, fundamental differences in work-care practices arose and different work-care policy paths were established in Czechoslovakia and East Germany in the 1970s. These then affected their populations' work-care related values, norms and beliefs, such as notions of good childcare and even attitudes toward gender roles.

The establishment of the same work-care policies in the late 1940s and early 1950s in Czechoslovakia and the GDR could be explained by the establishment of the state socialist regime, which in the first period implied transformations of all institutions according to the Soviet model. However, to explain why, when and how the two distinct work-care policy paths and work-care models developed in Czechoslovakia and the GDR, we had to develop a framework inspired by current discussions within institutionalist studies. While traditional institutionalist studies have tended to focus on explaining institutional continuity rather than change, and while change has usually been explained as a result of an exogenous shock, recent studies have increasingly sought to endogenize causes of institutional changes (Thelen 2004; Streeck/Thelen 2005). This has often meant a turn to actors and discourses (Pfau-Effinger 2005; Schmidt 2010). In our framework, we also stressed the role of influential actors and discourses. However, we added the effect of structural conditions and emphasized the interplay between a) work-care institutions (as constructs and outcomes of work-care policies and as structures that affect future policies), b) workcare related norms and values expressed in ideologies, beliefs and dominant discourses, and c) work-care practices. In our framework, these three elements directly or indirectly influence each other and constitute a prevalent work-care model. Structural conditions and influential actors further affect the model. The actors may strengthen specific discourses based on their ideas and bring about institutional change.

More specifically, in Czechoslovakia and the GDR, we identified the important difference in structural conditions regarding the necessity for increasing the workforce and influential actors who were able to promote different discourses in the 1960s. This difference in the structural conditions and influential actors (e.g. Schmidt-Kolmer and Institute for Social Hygiene in the GDR and Government Population Commission in Czechoslovakia) contributed to the establishment of different policies to solve the problems resulting from the modernized gender model. Czechoslovak policy focused on extending maternity leave, leading to sequencing women's life course. In contrast, the policy in the GDR focused on extending and improving public childcare as well as on slightly reducing the working hours of employed mothers. Moreover, in contrast to Czechoslovakia, the GDR enabled more mothers to work part-time. This led to women's continuous participation in employment in the GDR. The many years of the two distinct work-care practices within the context of distinct work-care policies then translated into radically distinct work-care related values and norms among the populations of the two countries. The well-accepted 
public childcare in the GDR and the three years of home-based paid childcare provided by mothers in Czechoslovakia became the social norms in the respective countries. Thus, the extensive dual-earner model with continuous women's careers was established in the GDR in the 1970s, while the extensive dual-earner model with interruptions in mothers' careers emerged in Czechoslovakia.

By applying the institutionalist approach, we explained the overall continuity of the two distinct work-care models despite the revolutionary changes that the countries experienced during the post-1989 transformation. Although the establishment of the Czech and Slovak Republics contributed to open up room for creating differences in work-care policies and practices, the policies continued to follow the policy path previously chosen and the work-care practices remained quite similar in the Czech Republic and Slovakia and the closest to each other in a European comparison. Similarly, in the case of East Germany, we showed how, based on the logic of appropriateness (expressed in the belief that not only mothers and the society but also children benefit from crèches), work-care policy hindered a policy change on the state and community level toward familialist policy after 1989 and rather followed the policy path previously chosen and the deeply rooted workcare model.

Institutionalist studies tend to explain how, based on the logic of appropriateness and institutional path, institutions create constraints for changing these institutions or establishing new policies. However, we also showed that establishing crèches as healthcare facilities and the norm and practice of home-based childcare for children under the age of three contributed to the abolishment of crèches in the Czech and Slovak Republics after 1990. The case of Czech and Slovak crèches shows that institutional path dependency can even explain why an established institution, like crèches, disappears.

Last but not least, in contrast to traditional institutionalist studies, which have explained institutional change as coming primarily from the outside as a result of exogenous shocks, we point out that current institutional changes in the sphere of work-care policies in the three countries did not happen as a consequence of the 1989 revolutionary period. The introduction of a new childcare allowance in Slovakia, the radical transformation of the old childcare allowance in the Czech Republic and the replacement of the old childcare allowance with Swedish-type parental leave on the federal level in Germany happened during a period of relative stability. More research is needed to explain why and how these recent institutional changes occurred.

\section{References}

Bicksel, É. (2006). 'Our greatest treasure, the child'. The politics of child care in Hungary, 1945-1956. Social Politics, 2/2006, pp. 151-188.

Bothfeld, S., Tobsch, V. \& Schmidt, T. (2005). Erosion des männlichen Ernährermodells? Die Erwerbstätigkeit von Frauen mit Kindern unter drei Jahren. Berlin: Bundesministeriun für Familie, Senioren, Frauen und Jugend.

Bothfeld, S. et al. (2005). WSI-Frauendatenreport. 2005. Berlin: edition sigma.

Buliřr, M. (1990). Zařizeni předškolní péče a výchovy v ČSR: retrospektiva let 1881-1988 a 1921-1988. Prague: Czech Statistical Office.

Čákiová, E. et al. (1977). Stručná zpráva z výzkumu Rodina a děti. Prague: KVVM FSÚ. 
Crompton, R. (Ed.) (1999). Restructuring gender relations and employment. The decline of the male breadwinner. Oxford/New York: Oxford University Press.

Czech Statistical Office (2010). Změny v zaměstnanosti a nezaměstnanosti v České republice v porovnání s ostatními zemémi EU. Prague: Czech Statistical Office.

European Commission (2008). Indicators for monitoring the employment guidelines including indicators for additional employment analysis 2008 compendium. Brussels: European Commission, DG ESAEO.

Gerbery, D. (2010). Public childcare in the Slovak Republic: Development, outcomes and public activities. In: A. Scharle (Ed.) Manka goes to work. Public childcare in the Visegrad countries 1989-2009. Budapest: Institute for Policy Affairs, pp. 110-127.

Háková, L. (1966). Ženy v sociální struktuře naší společnosti. In: Machonin, P. (Ed.), Sociální struktura socialistické společnosti. Prague: Svoboda, pp. 547-564.

Hašková, H. \& Saxonberg, S. (2010 forthcoming). "The institutional roots of post-communist family policy: Comparing the Czech and Slovak Republics.” In: M. L. Krook \& F. Mackay (Eds), Gender, politics, and institutions: Towards a feminist institutionalism. Palgrave.

Heinen, J. \& M. Wator (2006) Child care in Poland before, during, and after the transition: Still a women's business. Social Politics, 2/2006, pp. 189-216.

Historical Statistical Yearbook of Czechoslovakia (1985) Prague: SNTL Alfa.

Hobson, B. \& Fahlén, S. (2009). Applying Sen [']s capabilities framework to work family balance within a European Context: Theoretical and empirical challenges. Edinburgh: RECWOWE (Reconciling Work and Welfare in Europe) Publication, Dissemination and Dialogue Centre (REC-WP 03/2009).

Kenny, M. (2007). Gender, institutions and power: A critical view. Politics, 2/2007, pp. 91-100.

Klammer, U. et al. (2000). WSI-FrauenDatenReport 2000. Berlin: WSI.

Klenner, C. (2009). Wer ernährt die Familie? Erwerbs- und Einkommenskonstellationen in Ostdeutschland. WSI-Mitteilungen, 11/2009, pp. 619-626.

Klenner, C. \& Hašková, H. (2010). Variations of the dual earner model. Employment among mothers: A comparison of the Czech Republic and Germany. In: C. Klenner \& S. Leiber (Eds), Welfare states and gender in Central and Eastern Europe. Continuity and post-socialist transformation in the EU member states. Brussels: ETUI, pp. 181-218.

Klíma, M. (1969). Pečovetelská služba, jako forma péče o děti jeslového věku a důsledky vyplývající z jejich zavedeni. Brno: VUT.

Koch, J. (1963). Předškolni ditě - jeho vývoj a výchova. Prague: Čs. společnost pro šíření politických a vědeckých znalostí.

Kreipl, J. et al. (1979). Mínění a názory na postavení a úlohu žen v rodině. Prague: ÚVVM FSÚ.

Langmeier, J. \& Matějček, Z. (1974). Psychická deprivace v dětství. Prague: Avicenum.

Lewis, J. (1997). Gender and welfare regimes: Further thoughts. Social Politics, 2/1997, pp. 160-177.

Mahoney, J. (2000). Path dependence in historical sociology. Theory and society, 4/2000, pp. 507-548.

Mečír, M. (1962). Aby zdravě rostli. O dětech od narození do šesti let. Prague: Státní zdravotnické nakladatelství.

Nickel, H. M.(1993). „Mitgestalterinnen des Sozialismus“ - Frauenarbeit in der DDR. In: G. Helwig \& H. M. Nickel (Eds), Frauen in Deutschland 1945-1992, Berlin: Akademieverlag, pp. 233-256.

Niebsch, G., Grosch, C., Bossdorf, U. \& Graehn-Baumann, G. (2007). Gesundheit, Entwicklung und Erziehung in der frühen Kindheit, Wissenschaft und Praxis der Kinderbetreuung in der DDR. In: F. Bodo, D. Kirchhöfer \& C. Uhlig (Eds), Gesellschaft und Erziehung. Historische und Systematische Studien. Band 2. Bad Heilbrunn: Verlag Julius Klinkhardt.

Pascall, G. \& Kwak, A. (2005). Gender regimes in transition in Central and Eastern Europe. Bristol: The Policy Press.

Paterak, H. (1999). Institutionelle Früherziehung im Spannungsfeld normativer Familienmodelle und gesellschaftlicher Realität. Münster, New York, München, Berlin: Waxmann.

Pfau-Effinger, B. (2005). Development paths of care arrangements in the framework of family values and welfare values. In B. Pfau-Effinger \& B. Geissler (Eds), Care and social integration in European societies. Bristol: The Policy Press, pp. 21-45. 
Pfau-Effinger, B. (1998). Arbeitsmarkt- und Familiendynamik in Europa - Theoretische Grundlagen der vergleichenden Analyse. In: B. Geissler, F. Maier \& B. Pfau-Effinger (Eds), FrauenArbeitsMarkt. Der Beitrag der Frauenforschung zur sozio-ökonomischen Theorieentwicklung. Berlin: edition sigma, pp. 177-194.

Pierson, P. (2000). Increasing returns, path dependence, and the study of politics. American Political Science Review, 1/2000, pp. 251-67.

Reyer, J. (1996). Krippenforschung und Krippenpädagogik in der DDR. Neue Praxis. Zeitschrift für Sozialarbeit, Sozialpädagogik und Sozialpolitik, 4/1996, pp. 326-344.

Riedmann, A. et al. (2006). Working time and work-life balance in European companies. Luxembourg: Office for Official Publications of the European Communities.

Saxonberg, S. \& Sirovátka (2006). Failing family policy in post-communist Central Europe. Comparative Policy Analysis, 2/2006, pp. 189-206.

Saxonberg, S. \& Szelewa, D. (2007). The continuing legacy of the communist legacy. Social Politics 3/2007, pp. 351-379.

Schiller, M. et al. (1971). Péče o děti v ČSSR. Prague: SPN.

Schmidt, V. A. (2010). Taking ideas and discourses seriously: explaining change through discoursive institutionalism as the fourth 'new institutionalism'. European Political Science Review 1/2010, pp. $1-25$.

Schröter, U. (2009). Die DDR-Frauenorganisation im Rückblick. In: U. Schröter, R. Ullrich \& R. Ferchland (Eds), Patriarchat im Sozialismus. Berlin: Rosa-Luxemburg-Stiftung (Texte 65), pp. 11-63.

Srb, V. \& Kučera, M. (1959). Výzkum o rodičovství 1956. Prague: State Statistical Office.

Statistisches Bundesamt (2008). Familienland Deutschland. Begleitmaterial zur Pressekonferenz am 22. Juli 2008 in Berlin. Wiesbaden: Statistisches Bundesamt.

Statistisches Jahrbuch der DDR 1989 (1989). Berlin: Staatsverlag der DDR

Streeck, W. \& Thelen, K. (Eds) (2005). Beyond continuity: Institutional change in advanced political economies. Oxford: Oxford University Press.

Švejcar, J. (1985). Péče o ditě. Prague: Avicenum.

Szikra, D. (2010). Eastern European faces of familialism: Hungarian and Polish family policies from a historical perspective. In: A. Scharle (Ed.), Manka goes to work. Public childcare in the Visegrad countries 1989-2009. Budapest: Institute for Policy Affairs, pp, 85-87.

Thelen, K. (2004). How institutions evolve: The political economy of skills in Germany, Britain, the United States, and Japan. Cambridge: Cambridge University Press.

Trappe, H. (1995). Emanzipation oder Zwang? Frauen in der DDR zwischen Beruf, Familie und Sozialpolitik. Berlin: Akademie-Verlag.

Uhde, Z., Dudová, R., Pulkrábková, K. \& Soudková, Š. (2009). Report on the activities and political claims of majority women's NGOs and minoritised women's and gender-based NGOs or groups on care, and specifically on childcare in the Czech Republic since the end of the Second World War. Available at: http://www.femcit.org/files/WP2_WorkingpaperNo2. pdf.

United Nations. (1979). Criteria for assessing the effectiveness of child welfare policies. SOA/ ESDP/1979/3.

Voicu, M. (2004). Work and family life in Europe: Value patterns and policy making. In: W. Arts \& L. Halman (Eds), European values at the turn of the millenium. Leiden: Brill, pp. 231-251.

von Oertzen, C. \& Rietzschel, A. (1997). Das „Kuckucksei“ Teilzeitarbeit. Die Politik der Gewerkschaften im deutsch-deutschen Vergleich. In: G.-F. Budde (Ed.), Frauen arbeiten. Weibliche Erwerbstätigkeit in Ost- und Westdeutschland nach 1945. Göttingen: Vandenhoek \& Ruprecht, pp. 212-251.

Winkler, G. (Ed.) (1990). Sozialreport' '90, Daten und Fakten zur sozialen Lage in der DDR. Berlin: Die Wirtschaft.

Submitted on/Eingereicht am: 20.03.2010

Accepted on/Angenommen am: 27.10.2010 
Addresses of the authors/Anschriften der Autorinnen:

Hana Hašková, Ph.D.

Institute of Sociology of the

Academy of Sciences of the Czech Republic

Department Gender and Sociology

Jilská 1

11000 Praha

Czech Republic/Tschechische Republik

E-Mail: Hana.Haskova@soc.cas.cz

Dr. Christina Klenner

Wirtschafts- und Sozialwissenschaftliches Institut (WSI)

in der Hans Böckler Stifttung

Hans-Böckler-Straße 39

40476 Düsseldorf

Germany/Deutschland

E-Mail: Christina-Klenner@boeckler.de 